\title{
WORKING EFFECTIVELY WITH LEGACY CODE
}

\author{
Jan LAVRINČÍK
}

\section{ÚDRŽBA KÓDŮ PŘEVZATÝCH PROGRAMŮ}

(FEATHERS, M. C. Údržba kódi̊ převzatých programů. 1. vyd. Brno : Computer Press, 2009. 367 s. ISBN 978-80-251-2127-6.)

V roce 2009 přeložil Jiří Berka pro největší české nakladatelství zabývající se odbornou literaturou z oblasti ICT ojedinělou publikaci z oblasti programování. Kniha s původním názvem Working effectively with legacy code vyšla v roce 2004 v nakladatelství Prentice Hall a napsal ji Michael C. Feathers.

Autor knihy Michael C. Feathers je odborníkem nejen v oblasti objektově orientovaného programování, ale také v jazycích Java, C\# a $\mathrm{C}++$. Předkládá nám knihu se záměrem maximálně využít a zhodnotit vývoj převztých programů po stránce funkčnosti, spolehlivosti a ovladatelnosti.

Nároky na výborné programátory se stále zvyšují, dnes už nestačí jen vytvořit funkční aplikaci, ale musejí být zachovány standardy: př̀nositelnost, kompatibilita $\mathrm{s}$ řadou systémů, nízké nároky na hardware, velikost aplikace a řada dalších. Důkazem nám může být napřr. $\mathrm{v}$ technologicky nejrychleji se vyvíjejícím světě Formule 1 programátor Tadd Czapski, který

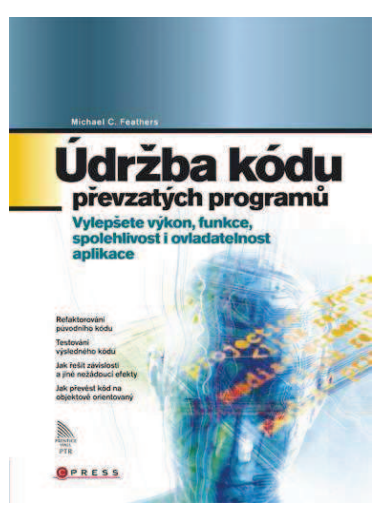
stál za vývojem software centrálních řídích jednotek motorů vítězných monopostů $\mathrm{F} 1$ od roku 2000 do roku 2006.

Kniha je rozdělená do tři hlavních oddílů s názvy mechanismus změn, modifikace softwaru a techniky rušení závislostí. Dále je kniha systematicky členěna do 25 kapitol dle oddílů. V kapitole s názvem modifikace softwaru se můžeme dočíst o přidání vlastnosti a odstranění chyby, zlepšení návrhu, optimalizaci zdrojových kódů z hlediska rychlosti. V druhé kapitole autor učí čtenáře pracovat se zpětnou vazbou, manuální a automatické metody testování aplikací, rušení závislostí, refaktorizace apod. Kapitola tři s názvem seznámení s kódem separace zavádí čtenáře do oblasti nepravých objektů. Kapitola čtyři nám přibližuje klasifikaci a práci se švy. Pátá, zároveň závěrečná kapitola prvního oddílu, je věnována nástrojům pro testování, zejména jednotkovým testovacím šablonám a obecným testovacím šablonám.

Druhý oddíl začíná zajímavým povídáním o pojmech metoda roubování, naroubovaná třída, obalová metoda, obalová tř́da. Kapitoly sedm a osm učí čtenáře porozumět logice kódu a možnosti řízení vlastností převzatých aplikací. $\mathrm{V}$ kapitole děvět a deset se autor zaměřil na základní obtíže tříd a jejich integraci do testovacích šablon. Kapitola jedenáct odhaluje kouzla s testováním dílčích částí a řízených procedur aplikace. Dvanáctá a trrináctá kapitola předkládá věcná doporučení, jak přistupovat k malým a rozsáhlejším změnám zdrojových kódů programů. Struktura kapitoly patnáct se opírá o externí knihovny typu dll a doplňky knihoven ocx. Když nerozumíme kódu natolik, abychom jej mohli měnit, můžeme nahlédnout do kapitoly šestnáct na metody rozdělení zodpovědnosti, porozumění struktuře metody, extrakci metod a v neposlední řadě pochopení vlivu změn. Kapitola sedmnáct nahlíží ,pod pokličku“ zdrojových kódů bez struktury. V osmnácté kapitole se naučíme o pravidlech zápisu a třídění testovacích kódů. Návod na otázku, jak postupovat ve zdrojových kódech z jazyků, které nejsou objektově orientovány, nám vyloží kapitola devatenáct. Strategie ovlivňování velikosti tříd je uvedeno v kapitole dvacet. Kapitola jedenadvacet radí, jak zvládnout změny stejných kódů na všech místech. Závěrečné kapitoly druhého oddílu dvaadvacet, dvacet tři a dvacet čtyři polemizují, jak bez testů odhalit kvalitu použitých strategií, metod a postupů zapsaných $\mathrm{v}$ převzatém zdrojovém kódu.

Třetí oddíl je do počtu stran tím nejchudším, tento handicap však kompenzuje obsahem. Kapitola je plná cenných rad, komplexních postupů a technik při rušení závislotí nebo refaktorování, které už je však označeno jako prríloha $\mathrm{A}$. Za prrílohou $\mathrm{B}$ každý programátor 
uvítá praktický výkladový slovníček z oblasti netradičních pojmů z oblasti programování a algoritmizace.

Recenzevaná kniha je napsána srozumitelným jazykem s vysokým odborným základem. Jelikož jsme mohli porovnat anglický originál s českým překladem, měnší výhrady, bychom mohli knize vytknout ve vyskytujících se chybách charakteru překlepů, vznikajících při překladu a následném přepisu textu, např. hned v obsahu najdeme údaj IiI, místo III.

Kniha má 367 stran plných zajímavých informací, graficky oddělených odstíny šedých rámů, či čar. Text je vhodně doplněn př́klady zdrojových kódů různé úrovně náročnosti a odvětví použití. Typickým prvkem knih s počítačovou tematikou je měkká vazba, jenž může mít vliv na mechanické opotřebení knihy. Obálka má moderní elegantní design. Cena knihy je v poměru k počtu stran přívětivých $450 \mathrm{Kč}$, což je vzhledem $\mathrm{k}$ tematice knihy nižší průměr.
V poslední době je trh přesycen celou řadou knih s podobnou tematikou, ale malokterá dosahuje kvalit teoretického aparátu s možností aplikace do praktického života. Recenzovaná kniha je spektrálně vyváženým základem vhodným primárně pro programátory, $\mathrm{k}$ doplnění nových př́stupů $\mathrm{k}$ vývoji a lazení převzatých aplikací. Své uplatnění může najít i v rámci celoživotního vzdělávání metodiků a lektorů programovacích jazyků a jako doporučená literatura pro studenty studijních oborů zaměřených na ICT.

Mgr. Jan Lavrinčík, DiS.

Katedra technické a informační výchovy

Pedagogická fakulta UP

Žižkovo nám. č. 5

771 40, Olomouc, ČR

Tel.: +420 585635813

E-mail: nobilis.felis@seznam.cz

Www pracovišstě: www.kteiv.upol.cz 